Original Article (short paper)

\title{
Behavioral health risk profiles of physical education undergraduates
}

\author{
Luciana Zaranza Monteiro ${ }^{1,2}$ (iD, Andrea Ramirez Varela ${ }^{2}$ (iD), Bruno Alves Lira ${ }^{1}$ (iD), Priscila de Souza ${ }^{1}$ (iD, \\ Daniel Junior de Oliveira Gomes ${ }^{1}$ (iD, Leonardo Chagas Contiero ${ }^{3}$ iD, José Maria Thiago Bonardi ${ }^{4}$ id \\ ${ }^{l}$ Centro Universitário do Distrito Federal, Departamento de Educação Física, Brasília, DF, Brasil; \\ ${ }^{2}$ Universidade Federal Pelotas, Programa de Pós-graduação em Epidemiologia, Pelotas, RS, Brasil; ; ${ }^{3}$ Centro \\ Universitário do Distrito Federal, Departamento de Biomedicina, Brasília, DF, Brasil, ${ }^{4}$ Universidade de São \\ Paulo, Escola de Medicina de Ribeirão Preto, Divisão de Medicina Interna Geral, Ribeirão Preto, SP, Brasil
}

\begin{abstract}
Aim: To analyze the prevalence of risky behaviors among physical education undergraduates; to determine prevalence of risk factors for non-communicable chronic diseases (NCCD) among university, and; to determine the association between healthy life habits and physical activity. Method: A cross-sectional study with 903 undergraduate Physical Education students. The study used a self-administered questionnaire on health-related life habits. All questions were obtained from the Surveillance of Risk and Protection Factors for Chronic Diseases through Telephone Interviews. Logistic regression was used to estimate odds ratios (OR) and 95\% confidence intervals $(95 \% \mathrm{CI})$. Results: Of the 903 students, $57.4 \%$ were women, $67.6 \%$ were between 20-29 years of age, $68.7 \%$ consumed alcohol, $28.5 \%$ did not do physical activity, and $33.2 \%$ were overweight. Regarding the eating habits considered a risk for NCCD, women exhibited more risk factors than men, whereas $41.1 \%$ drank more full-fat milk $(\mathrm{p}=0.01)$ and $31.8 \%$ ate more fatty meats, while men drank more soda $(\mathrm{p}<0.01)$. Physically active students consumed more fruits $(\mathrm{p}<0.01)$ and salads $(\mathrm{p}=0.01)$ and drank less soda $(p<0.01)$. The physically inactive students had a high prevalence of getting diabetes $(p<0.01)$ and of suffering from hypertension $(\mathrm{p}=0.01)$ and high cholesterol $(\mathrm{p}<0.01)$. Conclusions: University students in our study had unhealthy lifestyles. There is an urgent need for both a formulation and implementation of public health policies to promote health and decrease risk factors for NCCD.
\end{abstract}

Keywords: risk factors; lifestyle; chronic diseases; students; physical education.

\section{Introduction}

In recent decades, lifestyle has been recognised as an important determinant of health status and has become a focus of increasing research interest worldwide. The World Health Organization (WHO) has stated that $60 \%$ of an individual's health-related quality of life depends on his/her Lifestyle ${ }^{1}$. Numerous publications $^{2-4}$ have shown that healthy lifestyle practices reduce disease occurrence and mortality rates and socio-demographic dimensions such as sex, age, marital status, economic level, and paid employment correlate with healthy Lifestyle ${ }^{5}$.

Although it is difficult to change unhealthy habits that adults have adopted in their youth, many effects of health risk factors among adults are avoidable if these behaviours are identified and changed at an early stage ${ }^{6,7}$.

University students represent a major segment of the young adult population ${ }^{8}$. When students reach high school or university, the rapid changes in biological, emotional, cognitive, and social development influence their behavior. At this stage, adolescents and young people are normally curious and experiment with a variety of things which supposedly form part of growing up. In different societies, lines are drawn at such behav- ior, these behaviors are unacceptable and are considered harmful to them and the society'.

According to the collective imagination, healthcare students feature social responsibility regarding a healthy lifestyle ${ }^{10}$. Consequently, the practice of regular exercise and a balanced diet, in qualitative and quantitative terms, are viewed as an important factor in the promotion of health and quality of life ${ }^{11,12}$.

In this sense, diet and physical activity are only two of the many factors associated with well-being, quality of life, longevity, lifestyle and other aspects of a broader concept called health ${ }^{13}$.

In Brazil, studies involving university students of the physical education course are still scarce ${ }^{14}$. Therefore, it is critical to assess the at-risk behavior for non-communicable chronic diseases (NCCD) of these students in order to ensure short and long-term prevention and even intervention ${ }^{15}$.

Studies show that, in general, university students do not have a healthy lifestyle and most exhibit three or more risk behaviors for diabetes, hypertension and cardiovascular disease ${ }^{16}$. Moreover, the risk factors for NCCD will most likely be added to the list ${ }^{17}$.

However, it is believed that health students, specifically physical education students, the population of the present study, 
present a positive profile of health behavior, since they are actively involved in habits considered healthy and spread the importance of this idea ${ }^{13}$.

In addition, they will be professionals who will act as educators and motivators for the adoption of a healthy lifestyle by the population in general $^{14}$.

Therefore, this study examined the prevalence of risky behaviors among physical education undergraduates; to determine prevalence of risk factors for NCCD among university, and; to determine the association between healthy life habits and physical activity.

\section{Methods}

This cross-sectional study was conducted with undergraduate Physical Education students of a private institution in Brasilia (Midwest, Brazil).

The study population was composed of first to eighthsemester students who were in their classrooms on the day of data collection. A convenience sample consisted of 903 undergraduate students older than 18 years.

The number of participants was defined based on the guidelines on simple random sampling provided by Luiz and Magnanini $^{18}$. The number of students per course was taken into consideration for sample size calculation. The maximum tolerable error rate was $5 \%$ and the $95 \%$ confidence levels were indicated. We assumed a $50 \%$ prevalence for the outcome. Thus, the final sample consisted of 903 undergraduate Physical Education students.

\section{Instrument}

We used a self-administered questionnaire on health-related life habits. All questions were obtained from the Surveillance of Risk and Protection Factors for Chronic Diseases through Telephone Interviews ${ }^{19}$. The questionnaire monitored the main risk and protective factors for non-communicable chronic diseases (NCCD) among adults older than age 18 and is applied on an annual and continuous basis in all Brazilian states and the Federal District ${ }^{19}$.

The following demographic variables were included in the analysis: gender (male or female); age; socioeconomic level (based on the questionnaire of the ABEP-Brazilian Association of Research Companies) ${ }^{20}$; alcohol consumption (heavy drinking was defined as the consumption of five or more drinks in one sitting for men and four or more drinks in one sitting for women); smoking (yes/no); and health self-perception (excellent, very good, good, fair or poor), self-reported history of diseases, family history of hypertension, diabetes, high cholesterol, dyslipidemia and cardiovascular disease.

Specific questions were asked about the regularity and frequency of consumption of the following food items: fruit, greens/vegetables, and raw salad (on five or more days in a week-the recommended consumption frequency is five times a day or more, on five days a week or more); beans (on five or more days in a week); soft drinks (on five or more days in a week); full fat milk (on five or more days in a week); meat with excess fat (red meat with visible fat and/or chicken with skin).

Level of physical activity was classified as inactive (less than 150 minutes of moderate-intensity physical activity a week or less than 75 minutes of vigorous-intensity physical activity a week accumulated across work, home, transport or discretionary domains) or active (150 or more minutes of moderate-intensity physical activity a week). $\mathrm{WHO}^{21}$ has recommended that adults aged 18-64 years should do at least $150 \mathrm{~min}$ of moderateintensity physical activity per week.

Nutritional status was assessed by calculating body mass index (BMI) [weight in kilograms divided by the square of height in meters]. Self-reported weight and height, as well as cut-off points, were used in the calculation. Participants were classified as: underweight $(<18.5)$, normal weight (18.5-24.9), overweight (25-29.9) and obese $(\geq 30)^{22}$.

Concerning nutrition questions, non-communicable diseases protective factors were considered such as fruit and vegetables and beans consumption at least five or more times per week. Soft drinks consumption more than five times a week and the habit of consuming whole milk and meats with visible fats were considered as risk factors. A healthy life score was obtained, which was the sum of protective factors for NCCD, categorized from 1 to 5 points (low) and from 6 to 10 points (Moderate/High), where the greater the number of healthy habits referred by the participant, the more points the participant had.

\section{Procedure}

Data collection was performed between October 2016 and May 2017 by trained researchers. The instrument was administered during the break between lessons, in a classroom with a seating capacity for 60 students. Respondents had sufficient distance from each other to maintain confidentiality. The completed questionnaire was placed in an envelope containing the group name and the course session (morning and evening), and handed back to the researchers.

Before distributing the instrument for self-completion and the informed consent form for signing, the researchers briefly introduced themselves and explained the aims and methods of the study to the professor in charge of that particular class. Next, the researchers introduced themselves and the study project to the students and invited them to participate.

This study was approved by the Research Ethics Committee of the Centro Universitário do Distrito Federal-UDF (CAAE: 59713316.0.0000.5650 / protocol number 1.794.275).

\section{Statistical analysis}

Data are presented as absolute and relative frequencies and displayed with their respective $95 \%$ confidence intervals. The association between risk factors and sex and PA were analyzed using chi-square tests.

Odds ratio was calculated using logistic regression models to analyze if gender, age, and socioeconomic level are (moderate/high) healthy life score predictors. Crude and adjusted models were used in the assessment (for all variables together). 
Multiple correspondence analysis was conducted to test the joint relationship between risk factors for NCCD, gender, physical activity, and nutritional status. All statistical analyses were performed using the SAS Software, version 9.2, while correspondence analysis was conducted using SPSS, version 2.1. The level of significance was set at $5 \%$.

\section{Results}

A total of 903 students (who were 18 or older) out of the total of 1208 students enrolled in the program during the academic year of 2016 were included in the study. The loss of 305 students representing $25 \%$ of the population is because students did not attend the university on the day of data collection. A second attempt to include the students that missed the first day of data collection was made during another day. If the student missed both opportunities, he/she was not included in the study.

Of the studied population, $57.4 \%$ were women, $42.6 \%$ were men and most of the students, $67.6 \%$, were aged between 20 and 29 . Moreover, $57 \%$ of the university students were in the C social-economic class and 39.5\% stated their health was "good".

Table 1 describes the sample according to demographic, socioeconomic and health-related characteristics. In terms of habits, $68.7 \%$ of the students consumed alcoholic beverages, $28.5 \%$ did not exercise more than $150 \mathrm{~min} /$ week and $33.2 \%$ were overweight.

Table 2 shows the prevalence estimates for risk and protective factors for NCCD in the total population and according to gender, respectively. It was noted that $80.7 \%$ had a moderate/high health score ( 6 to 10 points). In relation to alcohol and tobacco use, the men drank and smoked more than the women, showing a statistical difference in tobacco use $(\mathrm{p}<0.01)$.

With regard to eating habits, the consumption of salad $(p=0.04)$, vegetables/legumes and beans was more prevalent among men, while the consumption of fruit was more prevalent among women.

In terms of dietary behaviors considered at risk for NCCD, the women exhibited more risk factors than the men. Of this population, $41.1 \%$ had a higher prevalence of consuming full-fat milk $(\mathrm{p}<0.01)$ and eating fatty means $(31.8 \%)$, although it was noted with a significant difference $(\mathrm{p}<0.01)$ that the men drank more soda $(25.7 \%)$.

A high prevalence of physically inactive students was also noted. Of these students, the women $(34.3 \%)$ were more physically inactive $(\mathrm{p}<0.01)$ and $4.2 \%$ were classified as obese.

Concerning self-referred diseases, a significant difference was observed in terms of gender in relation to high cholesterol, with a high prevalence among women $(17.3 \%, \mathrm{p}=0.02)$. Women also showed a high prevalence of hypertension, diabetes mellitus and dyslipidemia, without significant differences.

The studied group is a population at imminent risk for NCCD, in which the men had a higher prevalence for tobacco and alcohol use and a significant number of students had high cholesterol levels and exhibited unhealthy behaviors.

Table 3 shows the association between physical activity ( $>150 \mathrm{~min} /$ week) and protective and risk factors for NCCD, in
Table 1 - Description of the sample according to students's characteristics. Brasília, DF, Brazil, 2017.

\begin{tabular}{lcc}
\hline Variable & N & \% \\
\hline Sex & & \\
Female & 518 & 57.4 \\
Male & 385 & 42.6 \\
Age (years) & & \\
$\leq 19$ & 143 & 15.8 \\
$20-29$ & 610 & 67.6 \\
$\geq 30$ & 150 & 16.6 \\
Socioeconomic level & & \\
A & 23 & 2.6 \\
B & 230 & 25.5 \\
C & 515 & 57.0 \\
D & 135 & 15.0 \\
\end{tabular}

Self-perception of

health

\begin{tabular}{lcc} 
Excellent & 153 & 16.9 \\
Very good & 262 & 29.0 \\
Good & 357 & 39.5 \\
Fair & 109 & 12.1 \\
Poor & 22 & 2.4 \\
Smoking & & \\
Yes & 263 & 29.1 \\
No & 640 & 70.9 \\
Use of alcohol & & \\
Yes & 621 & 68.7 \\
No & 282 & 31.2 \\
Nutritional status & & \\
Underweight & 40 & 4.4 \\
Normal weight & 531 & 58.8 \\
Overweight & 300 & 33.2 \\
Obese & 32 & 3.5 \\
PA >150 min/week & & $\mathbf{1 0 0}$ \\
Yes & 646 & 71.5 \\
No & 257 & 28.5 \\
Total & $\mathbf{9 0 3}$ & \\
\hline & & \\
& &
\end{tabular}

addition to self-referred diseases among the students. The students who did physical activity according to recommendations $(>150 \mathrm{~min} /$ week) consumed more fruit $(\mathrm{p}<0.01)$, salad $(\mathrm{p}=0.01)$ and drank less soda $(\mathrm{p}<0.01)$.

An analysis of the association between physical inactivity and self-referred diseases revealed a high prevalence of diabetes mellitus $(p<0.01)$, hypertension $(p=0.01)$ and high cholesterol $(\mathrm{p}<0.01)$ among the students who did not exercise. 
Monteiro, L.Z. \& Varela, A.R. \& Lira, B.A. \& Souza, P. \& Gomes, D.J.O. \& Contiero, L.C. \& Bonardi, J.M.T.

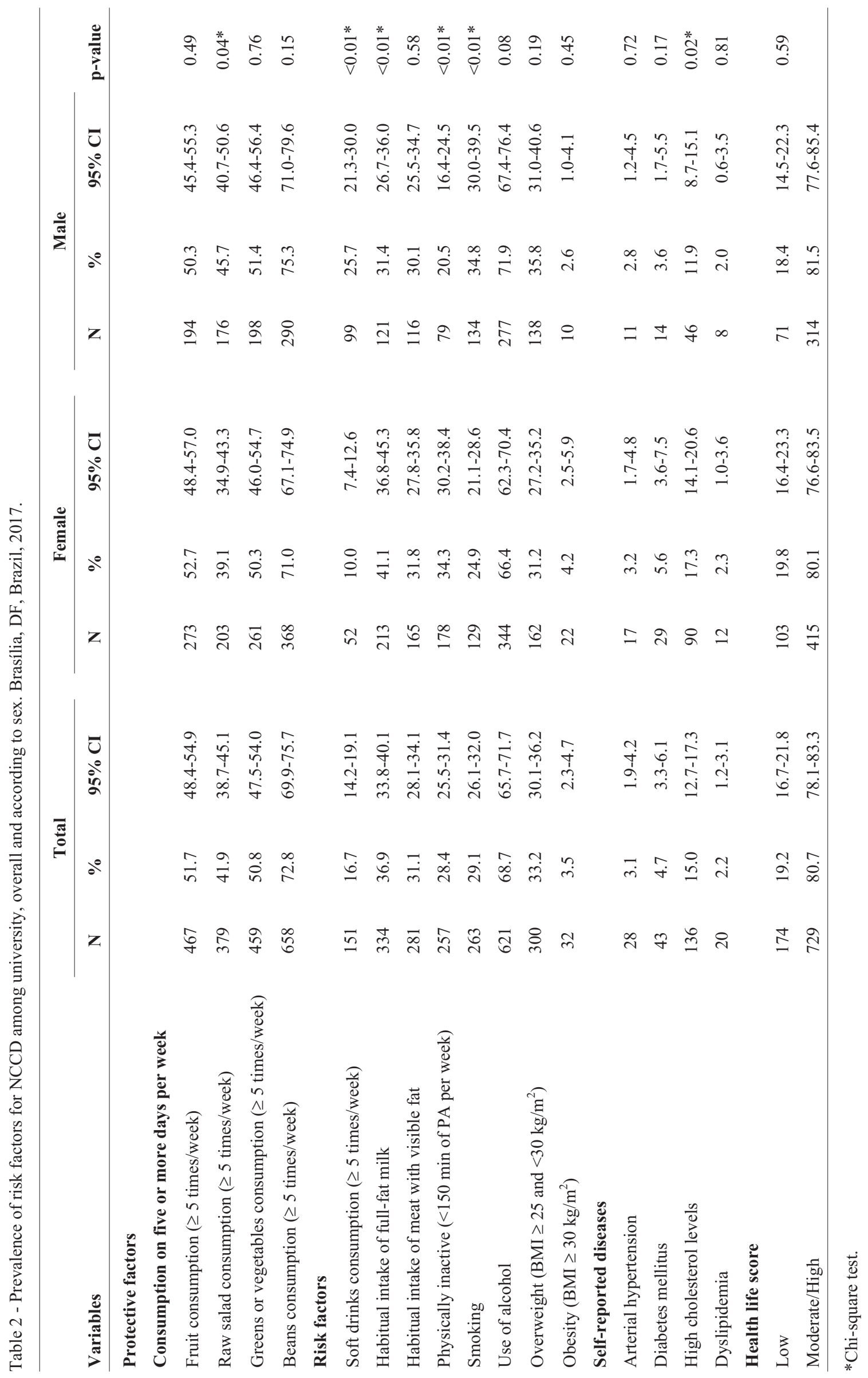


Table 3 - Association between healthy life habits and physical activity in undergraduate students.

\begin{tabular}{|c|c|c|c|c|c|c|c|}
\hline \multirow[t]{3}{*}{ Variables } & \multicolumn{6}{|c|}{ PA $>150 \mathrm{~min} /$ weeks } & \multirow[t]{3}{*}{ p-value } \\
\hline & \multicolumn{3}{|c|}{ No $(n=257)$} & \multicolumn{3}{|c|}{ Yes $(n=646)$} & \\
\hline & $\mathbf{N}$ & $\%$ & $95 \%$ CI & $\mathbf{N}$ & $\%$ & $95 \%$ CI & \\
\hline \multicolumn{8}{|c|}{ Nutritional status } \\
\hline Underweight & 14 & 5.4 & $2.6-8.2$ & 26 & 4.0 & $2.5-5.5$ & \\
\hline Normal weight & 144 & 56.0 & $49.9-62.1$ & 387 & 59.9 & $56.1-63.6$ & 0.57 \\
\hline Overweight & 91 & 35.4 & $29.5-41.2$ & 209 & 32.3 & $28.7-35.9$ & \\
\hline Obese & 8 & 3.1 & $0.9-5.2$ & 24 & 3.7 & $2.2-5.1$ & \\
\hline \multicolumn{8}{|c|}{ Alcohol consumption } \\
\hline No & 84 & 32.6 & $26.9-38.4$ & 198 & 30.6 & $27.0-34.2$ & 0.55 \\
\hline Yes & 173 & 67.3 & $61.5-73.0$ & 448 & 69.3 & $65.7-72.9$ & \\
\hline \multicolumn{8}{|l|}{ Smoking } \\
\hline No & 180 & 70.0 & $64.4-75.6$ & 460 & 71.2 & $67.7-74.7$ & 0.73 \\
\hline Yes & 77 & 29.9 & $24.3-35.5$ & 186 & 28.7 & $25.3-32.2$ & \\
\hline \multicolumn{8}{|c|}{ Consumption of fruit ( $\geq 5$ times/week) } \\
\hline No & 152 & 59.1 & $53.1-65.1$ & 284 & 43.9 & $40.1-47.7$ & $<0.01^{*}$ \\
\hline Yes & 105 & 40.8 & $34.8-46.8$ & 362 & 56.0 & $52.2-59.8$ & \\
\hline \multicolumn{8}{|c|}{ Consumption of salad ( $\geq 5$ times/week) } \\
\hline No & 166 & 64.5 & $58.7-70.4$ & 358 & 55.4 & $51.5-59.2$ & $0.01 *$ \\
\hline Yes & 91 & 35.4 & $29.5-41.2$ & 288 & 44.5 & $40.7-48.4$ & \\
\hline \multicolumn{8}{|c|}{ Consumption of greens ( $\geq 5$ times/week) } \\
\hline No & 138 & 53.7 & $47.6-59.8$ & 306 & 47.3 & $43.5-51.2$ & 0.09 \\
\hline Yes & 119 & 46.3 & $40.2-52.4$ & 340 & 52.6 & $48.7-56.4$ & \\
\hline \multicolumn{8}{|c|}{ Consumption of beans ( $\geq 5$ times/week) } \\
\hline No & 74 & 28.7 & $23.2-34.3$ & 171 & 26.4 & $23.0-29.8$ & 0.48 \\
\hline Yes & 183 & 71.2 & $65.6-76.7$ & 475 & 73.5 & $70.1-76.9$ & \\
\hline \multicolumn{8}{|c|}{ Consumption of soft drinks ( $\geq 5$ times/week) } \\
\hline No & 237 & 92.2 & $88.9-95.4$ & 515 & 79.7 & $76.6-82.8$ & $<0.01 *$ \\
\hline Yes & 20 & 7.7 & $4.5-11.0$ & 131 & 20.2 & $17.1-23.3$ & \\
\hline \multicolumn{8}{|c|}{ Consumption of full fat milk } \\
\hline No & 162 & 63.0 & $57.1-68.9$ & 407 & 63 & $59.2-66.7$ & 0.99 \\
\hline Yes & 95 & 36.9 & $31.0-42.8$ & 239 & 37 & $33.2-40.7$ & \\
\hline \multicolumn{8}{|c|}{ Consumption of meat with visible fat } \\
\hline No & 169 & 65.7 & $59.9-71.5$ & 453 & 70.1 & $66.5-73.6$ & 0.20 \\
\hline Yes & 88 & 34.2 & $28.4-40.0$ & 193 & 29.8 & $26.3-33.4$ & \\
\hline \multicolumn{8}{|c|}{ Arterial hypertension } \\
\hline No & 243 & 94.5 & $91.7-97.3$ & 632 & 97.8 & $96.7-98.9$ & $0.01 *$ \\
\hline Yes & 14 & 5.4 & $2.6-8.2$ & 14 & 2.1 & $1.0-3.2$ & \\
\hline \multicolumn{8}{|c|}{ Diabetes mellitus } \\
\hline No & 233 & 90.6 & $87.1-94.2$ & 627 & 97.0 & $95.7-98.3$ & $<0.01^{*}$ \\
\hline Yes & 24 & 9.3 & $5.7-12.9$ & 19 & 2.9 & $1.6-4.2$ & \\
\hline \multicolumn{8}{|c|}{ High cholesterol levels } \\
\hline No & 197 & 76.6 & $71.4-81.8$ & 570 & 88.2 & $85.7-90.7$ & $<0.01^{*}$ \\
\hline Yes & 60 & 23.3 & $18.1-28.5$ & 76 & 11.7 & $9.2-14.2$ & \\
\hline \multicolumn{8}{|l|}{ Dyslipidemia } \\
\hline No & 253 & 98.4 & $96.9-99.9$ & 630 & 97.5 & $96.3-98.7$ & 0.40 \\
\hline Yes & 4 & 1.5 & $0.0-3.0$ & 16 & 2.4 & $1.2-3.6$ & \\
\hline
\end{tabular}

*Chi-square test. 
No association was found between the healthy living score (low vs. moderate/high) and gender, age and socioeconomic status (Table 4).

Table 5 shows that the variables gender, age and socioeconomic status are associated with a healthy living score, but no relationship between the healthy life score and these variables was detected.

Figure 1 shows the relationship between the NCCD risk factors, gender, physical activity, and nutritional status, by using multiple correspondence analyses.

The graph indicates that participants with high cholesterol tend to also have hypertension and dyslipidemia. The proximity of the data in the chart indicates an association and it was noted that the obese students tended to have high blood pressure and cholesterol and dyslipidemia.

As for the remaining factors, it was not possible to identify a defined profile since the points are very close to the origin. The

Table 4 - Association between health life score and sex, age and socioeconomic level.

\begin{tabular}{lcc}
\hline Variable & Healthy Life Score & p-value \\
\cline { 2 - 3 } & Low $(n=174)$ & $\begin{array}{c}\text { Moderate/high } \\
(n=729)\end{array}$ \\
\hline
\end{tabular}

\begin{tabular}{lccc}
\hline Sex & & & \\
Female & $103(59.2 \%)$ & $415(56.9 \%)$ & 0.59 \\
Male & $71(40.8 \%)$ & $314(43.0 \%)$ & \\
Age (years) & & \\
$\leq 19$ & $23(13.2 \%)$ & $120(16.4 \%)$ & \\
$20-29$ & $123(70.6 \%)$ & $487(66.8 \%)$ & 0.53 \\
$\geq 30$ & $28(16.0 \%)$ & $122(16.7 \%)$ & \\
Socioeconomic level & \\
A & $4(2.3 \%)$ & $19(2.6 \%)$ & \\
B & $49(28.1 \%)$ & $181(24.8 \%)$ & \\
C & $91(52.3 \%)$ & $424(58.1 \%)$ & 0.52 \\
D & $30(17.2 \%)$ & $105(14.4 \%)$ & \\
\hline
\end{tabular}

Chi-square test. low percentage of explanations may be caused by a large number of analyzed variables.

\section{Discussion}

Risky behaviors can significantly affect the lives of the youth and those around them. Parents, educators, and other concerned adults must become aware of the prevalence of these behaviors and plan programs that can reduce or prevent them ${ }^{23}$.

This study revealed important aspects regarding the health of Brazilian university students. The sociodemographic profile was composed mostly of women, between 20 and 29 years of age, with a low family income ( 3 to 5 minimum wages-class $\mathrm{C}$ ). Regarding self-referred diseases, $15 \%$ claimed they had high cholesterol. It was noted that $80.7 \%$ had a moderate/high health score (6 to 10 points).

Another relevant factor in this study is the importance of studying physical education students since their work will be related to preventing diseases and promoting health. Therefore, in the academic setting, it is believed they should be prepared to work with preventive actions.

With respect to the sample group, most of the subjects were women, which could be justified by the higher percentage of women in health-related courses. In accordance with the results of this study, a previous study ${ }^{24}$ on alcohol use found that most of the subjects were men $(61.6 \%)$ and only $38.4 \%$ were women, as also found in several other works on alcohol use, thus corroborating other findings ${ }^{25}$.

Although many antismoking campaigns are promoted by the Ministry of Health in Brazil, initiation into smoking chiefly happens during adolescence ${ }^{26}$. A study conducted with adolescents and adults from Belo Horizonte found that $51 \%$ of participants were smokers ${ }^{27}$. In Colombia, a study revealed that $80 \%$ of nursing undergraduates are smokers ${ }^{28}$. This is a significantly higher percentage than the one found in this study (29.1\%). This difference may be explained by the social and cultural characteristics of the region where the study was conducted. Several studies in Brazil and globally, have shown the higher smoking prevalence among men than women ${ }^{28}$. The gender differences in smoking prevalence may be explained by cultural and religious

Table 5 - Predictive factors of moderate/high healthy life score.

\begin{tabular}{|c|c|c|c|c|c|c|c|c|}
\hline $\begin{array}{l}\text { Likelihood modeled in } \\
\text { Score='moderate/high }\end{array}$ & & & & & & & & \\
\hline Effect & Crude odds & & & p-value & Adjusted & & & p-value \\
\hline Sex (male vs female) & 1.10 & 0.78 & 1.54 & 0.59 & 1.13 & 0.80 & 1.58 & 0.49 \\
\hline Age $(20-29$ vs $\leq 19)$ & 0.76 & 0.47 & 1.24 & 0.56 & 0.75 & 0.46 & 1.23 & 0.26 \\
\hline Age $(>30$ vs $\leq 19)$ & 0.84 & 0.46 & 1.53 & 0.27 & 0.83 & 0.45 & 1.52 & 0.54 \\
\hline Socioeconomic level (A vs D) & 1.36 & 0.43 & 4.30 & 0.60 & 1.38 & 0.43 & 4.37 & 0.59 \\
\hline Socioeconomic level (B vs D) & 1.06 & 0.63 & 1.77 & 0.84 & 1.07 & 0.64 & 1.78 & 0.81 \\
\hline Socioeconomic level (C vs D) & 1.33 & 0.83 & 2.19 & 0.23 & 1.35 & 0.85 & 2.16 & 0.20 \\
\hline
\end{tabular}




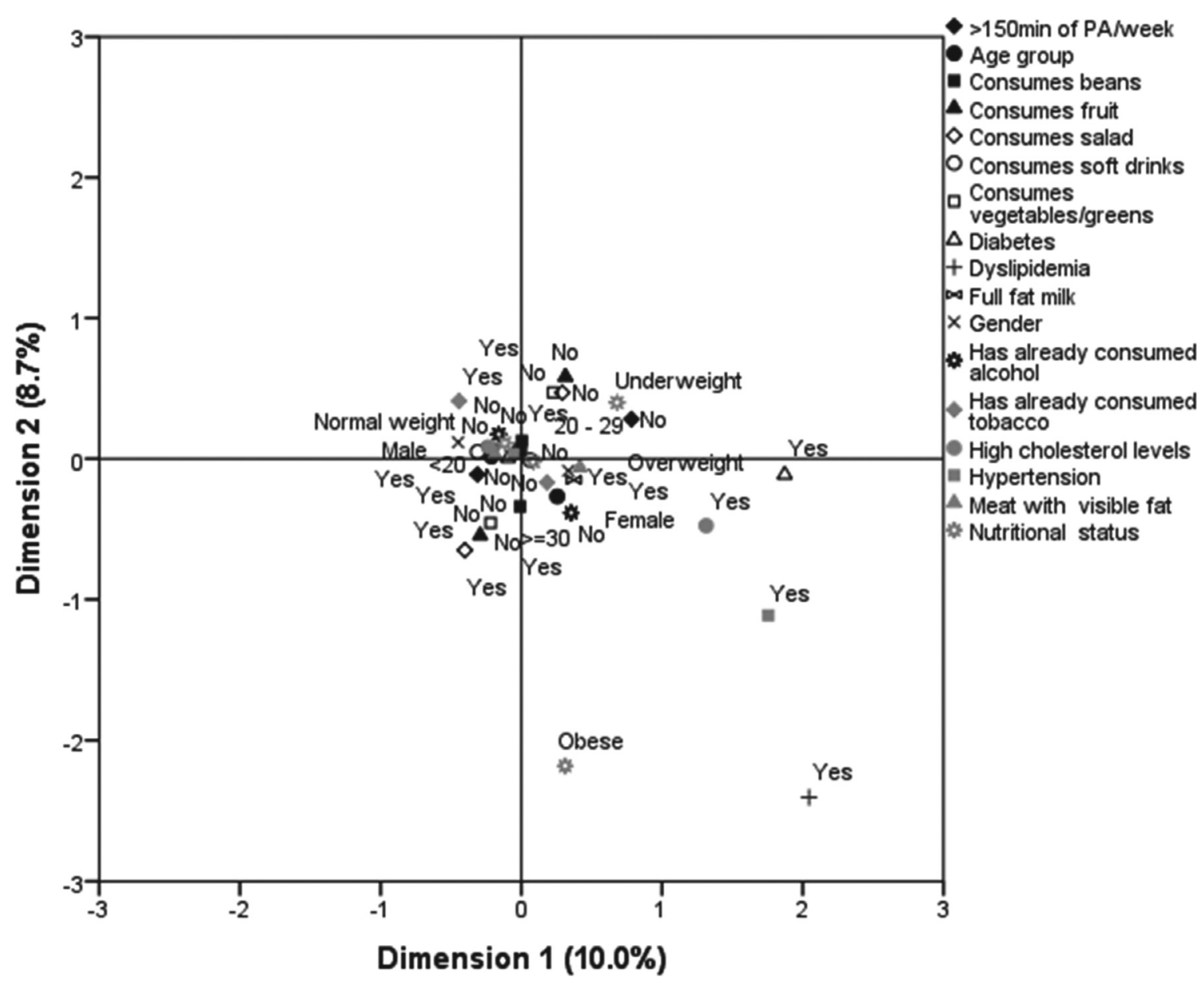

Figure 1 - Joint relationship between risk factors, sex, physical activity and nutritional status of university students.

factors. Tobacco was originally introduced among men and has been associated with a symbol of masculinity and power ${ }^{28}$.

Our study showed a prevalence of alcohol consumption and tobacco use among Physical Education undergraduates of $68.7 \%$ and $29.1 \%$, respectively ${ }^{29}$. This is rather a worrying result since alcohol and tobacco use is associated with several behavioral disorders and health problems.

The highest percentages were recorded in the age group 20 to 29 years. Similar results were found in another study, which also identified an association between the casual use of alcohol and the use of psychoactive drugs ${ }^{25}$.

In this study, the prevalence of alcohol consumption was higher $(68.7 \%)$ than in British students $(25-42 \%)^{30}$, medical students from public and private universities in the USA $(6-12 \%)^{31}$ and medical students in Crete, Greece $(3.6 \%)^{32}$.

A national survey on the consumption of alcohol among university students that was

performed in Brazil in 2010 found revealed that $86.2 \%$ of respondents had used alcohol at least once in their lives ${ }^{26}$. When comparing the results of the aforementioned survey with the First National Survey on the Patterns of Alcohol Consumption in the Brazilian Population in 2007, we found that $52 \%$ of people older than 18 years had consumed alcohol at least once in the previous 12 months, whereas $48 \%$ were abstinent ${ }^{26}$.
The majority of our sample $(56.7 \%)$ was within a normal weight. This agrees with the results of other studies ${ }^{15}$, in which normal weight was also more prevalent among university students.

These risk factors are complemented by the anthropometric profile. Men showed a higher prevalence of overweight, whereas women demonstrated a higher prevalence of obesity.

This was also found by Gasparotto, Gasparotto, Salles, Campos $^{33}$, who investigated risk factors for the development of cardiovascular diseases in 1,600 university students and found a higher incidence of overweight in men $(32 \%)$ than in women $(20 \%)$. Petrib, Cabral, Arruda ${ }^{34}$ corroborate conducted a study with 250 university students in Recife, Brazil. Their findings corroborate other studies in which the prevalence of overweight among women was significantly lower than that of men $(5.3 \%$ and $35.5 \%$, respectively).

Peltzer and Pengpid ${ }^{35}$ assessed nutritional status and associated factors in 15,068 university students from 21 underdeveloped and developing countries and found a prevalence of overweight and obesity of $61.1 \%$ (41\% in men and $25.1 \%$ in women) and $27 \%$, respectively. In India, studies indicate a prevalence of overweight in men and women of 37.5 and $26.8 \%$, respectively ${ }^{36}$.

Costa e Vasconcelos ${ }^{37}$ assessed the body weight of $220 \mathrm{fe}-$ male freshmen students of a university in Florianópolis, SC, 
Brazil, and found that $72.3 \%$ of them were normal weight, $11.8 \%$ were overweight and $3.2 \%$ were obese. This disagrees with the results of previous studies, which show a low prevalence of consumption of fruit and vegetables (less than five days a week) among undergraduate health students $(44 \%)^{38}$.

A 10-year-study monitored health indicators and quality of life of 1,232 university students in Bahia, Brazil, and found an insufficient consumption of fruit and vegetables by $81.2 \%$ and $57 \%$ of participants, respectively ${ }^{39}$.

The Surveillance of Risk and Protection Factors for Chronic Diseases through Telephone Interviews ${ }^{19}$ evidenced that Brazilians do not regularly consume fruit and vegetables. Moreover, between-sex comparison demonstrated that men $(17.6 \%)$ consume less than women (39.2\% versus $49.8 \%)$.

The marked prevalence of high full-fat milk consumption by women $(41.1 \%)$ is worrisome, as this habit is associated with the global risk of cardiovascular diseases, such as coronary heart disease and stroke ${ }^{16}$. The habit of consuming fatty meat was not assessed in other studies conducted with university students. In this study, the women had a high prevalence of consuming fatty mean $(31.8 \%)$. The high intake of saturated fats and cholesterol-rich foods due to the habit of consuming animal fat increases the risk of coronary heart disease, ischemic stroke, and other cardiovascular diseases. This diet habit is also considered a risk factor for the development of dyslipidemias ${ }^{40}$. These facts highlight the need to investigate the excessive consumption of animal fat and increase awareness of university students regarding the consequences of this habit.

Another important health-risk behavior is the low level of physical activity among students, and the women showed even lower levels. In a study conducted with students at a university in the State of Santa Catarina, southern Brazil, the women were more sedentary than the men, and $17.4 \%$ of them were inactive $^{32}$. This physical inactivity can be explained by the fact that women have more activities besides university duties, such as taking care of their children, domestic work, and also economic issues, thus providing less time to practice physical activity.

These data corroborate ${ }^{41}$ a higher level of physical inactivity among women. There are studies in the literature that show that age modifies the practice of physical activity with a greater decline among young people from 18 to 25 years old, which is related to the transition to higher education ${ }^{42}$.

The prevalence of physical inactivity was higher in women, corroborated by a study where the prevalence was higher in women with dependents at home (children and/or sick people), related to the historical roles of wife, mother and caregiver held by women ${ }^{41}$. This also corroborates the findings of another study, in which the high presence of children at home made it difficult to practice physical activity when there were no caretakers to leave their children with ${ }^{43}$. Another study showed that family obligations and income were associated with physical inactivity in the entire population (45.4\%) and, for women, such obligations were statistically significant ${ }^{44}$.

The researchers highlight that females have 1.7 times greater chance of physical inactivity when compared with men ${ }^{42}$, this finding is consistent with previous study reported in the literature $^{43}$.
Several factors are mentioned in the literature as the main reason for the absence or abandonment of the practice of physical activity. Research conducted with students from the University of Mansoura (Egypt) shows that lack of time and motivation, few safe places to practice sports and lack of incentives are the most reported causes for physical inactivity in this population $^{45}$. Lack of time, however, is the main reason why college students, especially women, stop doing physical activity.

For Mielke, Ramis, Habeyche, Oliz, Tessmer, Azevedo, Hallal $^{46}$, the sex differences are related to preference, while men adhere to sports and group activities (soccer, volleyball, basketball), women prefer individual activities (swimming, walking, cycling). The reason for this difference in adherence to physical activity between genders can also be explained due to motivational factors, as men are more intrinsically motivated and seek for challenges and fun while women are more extrinsically motivated and aim to improve their appearance, weight maintenance, and health care ${ }^{47}$.

The predominance of class $\mathrm{C}$ individuals in this study may also have contributed to the increased prevalence of physical inactivity among students. In a study that evaluated the association between physical inactivity and socioeconomic status, the highest prevalence of physical inactivity was also found in people of classes $C$ and $D^{48}$. A possible explanation for this behavior is the lack of time since the type of work in these social classes is demanding and takes up a great deal of time, while the lack of suitable public places for practicing physical activity may also contribute to this high prevalence ${ }^{49}$.

Previous studies indicate that university students are becoming increasingly inactive and that healthcare undergraduates tend to engage in less physical activity than their peers ${ }^{50}$.

Florindo, Brownson, Mielke, Gomes, Parra, Siqueira ${ }^{51}$ demonstrated an association between the level of physical activity (PA) and fruit and vegetable consumption among university students. Pinho et al. ${ }^{52}$, however, did not find such associations. This study showed a significant association between physical inactivity and lower consumption of fruits and vegetables. This fact corroborates the possible existence of concomitant behaviors that favor the occurrence of $\mathrm{NCD}^{53}$. In this study, such behaviors are a diet poor in fruit and vegetables and physical inactivity.

Gasparotto el at. ${ }^{33}$ found that about $55 \%$ of undergraduate students in the fields of Biological and Exact sciences and $\mathrm{Hu}-$ manities undertook less than 150 minutes of physical activity per week. This evidences that only a little less than half of the sample meets the recommended levels of physical activity. In this study, a between-sex comparison demonstrated that women $(34.3 \%)$ were more sedentary than men $(p<0.01)$.

Since university students, especially in the fields of health sciences, will become opinion-makers in their professions and since they are considered multipliers of a healthy lifestyle, the effects of the health-related behavior of physical education students on their future practice are hereby questioned. We observed that inactive students presented more morbidities and inadequate eating habits, these factors can be explained by the fact that physical inactivity provides a high prevalence of chro- 
nic diseases, as well as the appearance of metabolic and physiological alterations, such as obesity and diabetes.

It is noticeable that the risk factors tend to cluster in the student population. A study conducted with university students showed that $86 \%$ exhibited three or more risk factors ${ }^{54}$.

The present study has some limitations. Firstly, the sectional design does not allow the establishment of a time relationship between the variables of interest in this research. Secondly, although risk factors for NCCD were assessed with a standardized and validated questionnaire, the use of self-reporting methods to collect data might have caused some errors in estimation. Thirdly, the study sample included a much higher number of females than males.

Identifying the population groups that are most exposed to risk factors and behaviors for NCCD (such as sedentary lifestyle) is critical for the design and implementation of actions aimed at reducing their incidence.

\section{Conclusions}

This study revealed that the participants had several NCCD risk factors, that is, a high prevalence of alcohol use, physical inactivity, the consumption of meat and full-fat milk and the low consumption of salads.

In comparison to women, men consumed more alcohol and soda and less fruit. It should be noted that women had a greater number of self-referred diseases, particularly high cholesterol.

Encouraging a healthy lifestyle is a challenge for todays health workers, managers, and public and private authorities. With the recent public policies geared toward promoting health in Brazil, considerable advancements have been made in this area, as shown in the evolution of population survey data.

Thus, the data from this study can contribute to the creation and development of projects in higher education institutions aiming to encourage a healthier lifestyle.

\section{References}

1. Ziglio E, Currie C, Rasmussen VB. The WHO crossnational study of health behavior in school-aged children from 35 countries: findings from 2001-2002. J Sch Health. 2004; 74(6): 204206. DOI: $10.1111 / \mathrm{j} .1746-1561.2004 . t b 07933 . x$

2. Nothlings U, Ford ES, Boeing H. Lifestyle factors and mortality among adults with diabetes: findings from the European Prospective Investigation into Cancer and Nutrition-Potsdam study. J Diabetes. 2010; 2(2): 112-117. DOI: 10.1111/j.17530407.2010.00069.x.

3. Hu FB, Liu Y, Willett WC. Preventing chronic diseases by promoting healthy diet and lifestyle: public policy implications for China. Obes Rev. 2011; 12(7): 552-559. DOI: 10.1111/j.1467789X.2011.00863.x

4. Reddy P, Rankins D, Timoshanko A, Dunbar J. Life! in Australia: translating prevention research into a large-scale intervention. Br J Diabetes Vasc Dis. 2011; 11(4): 193-197. DOI: 10.1177/1474651411410724

5. Krueger PM, Chang VW. Being poor and coping with stress: health behaviors and the risk of death. Am J Public Health. 2008; 98(5): 889-896. DOI: 10.2105/AJPH.2007.114454
6. Landsberg B, Plachta-Danielzik S, Lange D, Johannsen M, Seiberl J, Muller MJ. Clustering of lifestyle factors and association with overweight in adolescents of the Kiel Obesity Prevention Study. Public Health Nutr. 2010; 13(10): 1708-1715. DOI: $10.1017 / \mathrm{S} 1368980010002260$

7. Pullman AW, Masters RC, Zalot LC, Carde LE, Saraiva MM, Dam YY, et al. Effect of the transition from high school to university on anthropometric and lifestyle variables in males. Appl Physiol Nutr Metab. 2009; 34(2): 162-171. DOI: 10.1139/H09007

8. Melissa NL, Keryn EP, Lust K, Story M, Ehlinger E. Latent class analysis of lifestyle characteristics and health risk behaviors among college youth. Prev Sci. 2009; 10(4):376-386. DOI:10.1007/s11121-009-0140-2

9. Kann L, Kinchen S, Shanklin SL, Flint KH, Kawkins J, Harris WA, et al. Youth risk behavior surveillance-United States, 2013. MMWR Morb Wkly Rep. 2014; 63 (26):576.

10. Castro JBP, Carvalho MCVS, Ferreira FR, Prado SD. "Faça o que eu digo, mas não faça o que eu faço!”: a décalage como ferramenta para compreensão de práticas corporais e alimentares. Rev Nutr. 2015; 28(1): 99-108. DOI: http://dx.doi.org/10.1590/1415-52732015000100009

11. Andrade MLL, Borges JSJ, Maia MMO, Silva FG. Nível de atividade física e ingestão energética em graduandos de educação física. Rev Bras Fisiol Exercício. 2013; 12(2): 114-118.

12. Hoefelmann LP, Lopes AS, Silva KS, Silva SG, Cabral LGA, Nahas MV. Lifestyle, self-reported morbidities, and poor sleep quality among Brazilian workers. Sleep Med. 2012; 13(9):11981201. DOI: 10.1016/j.sleep.2012.05.009

13. Pirajá GA, Sousa TF, Fonseca AS, Barbosa AR, Nahas MV. Autoavaliação positiva de estresse e prática de atividades físicas no lazer em estudantes universitários brasileiros. Rev Bras Ativ Fis Saúde. 2013; 18(6): 740-749. DOI: 10.12820/rbafs.v.18n6p740

14. Hosseini M, Ashktorab T, Taghdisi MH, Vardanjani AE, Rafiei $H$. Health-promoting behaviors and their association with certain demographic characteristics of nursing students of Tehran City in 2013. Glob J Health Sci. 2014; 7(2): 264-272. DOI: $10.5539 /$ gjhs.v7n2p264.

15. Colares V, Franca C, Gonzalez E. Condutas de saúde entre universitários: diferenças entre gêneros. Cad Saúde Pública. 2009; 25(3):521-528. DOI: $10.1590 / \mathrm{S} 0102-$ $311 \mathrm{X} 2009000300007$

16. Sousa TF, Jos HPM, Barbosa AR. Condutas negativas à saúde em estudantes universitários. Ciênc. saúde coletiva. 2013; 18(2):3563-3575. DOI: 10.1590/S1413-81232013001200013

17. Alves EF. Estilo de vida de estudantes de graduação em enfermagem de uma instituição do sul do Brasil. Rev CPAQV. 2011;3(1):1-14.

18. Luiz RR, Magnanini MMF. A lógica da determinação do tamanho da amostra em investigações epidemiológicas. Cadernos Saúde Coletiva. 2000; 8(2): 9-28.

19. Brasil. Ministério da Saude (BR). Secretaria de Vigilância em Saúde. Vigitel Brasil: vigilância de fatores de risco e proteção para doenças crônicas por inquérito telefônico. Brasília: Ministério da Saúde; 2014.

20. Associação Brasileira de Empresas de Pesquisa. Critério de classificação econômica Brasil, 2016.

21. World Health Organization (WHO). Global recommendations on physical activity for health. WHO, Geneva, 2010. Available from:

http://www.who.int/dietphysicalactivity/global-PA-recs-2010.p df [Accessed 27th July 2017]. 
22. World Health Organization (WHO). Obesity: preventing and managing the global epidemic. Geneva: World Health Organization; 2000. Available from: http://apps.who.int/bookorders/anglais/detart1.jsp?sesslan=1\&c odlan=1\&codcol=10\&codcch=894 [Accessed 24th July 2018].

23. Memish ZA, Jaber S, Mokdad AH, AlMazroa MA, Murray CJ, Al Rabeeah AA, et al. Burden of disease, injuries, and risk factors in the Kingdom of Saudi Arabia, 1990-2010. Prev Chronic Dis. 2014;11:E169. DOI: 10.5888/pcd11.140176

24. Barbosa FL, Barbosa RL, Aguiar DL, Ribeiro AC, Figueiredo IA, Ribeiro AC, et al. Uso de álcool entre estudantes de medicina da Universidade Federal do Maranhão. Rev bras educ med. 2013;37(1):89-95. DOI:10.1590/S0100-55022013000100013

25. Martinho AF, Tonin CL, Nunes LM, Novo NF, Hubner CVK. Uso de álcool e drogas por acadêmicos dos cursos de enfermagem, biologia e medicina na pontifica universidade católica de São Paulo. Rev Fac Ciênc Méd Sorocaba. 2009;11(1):11-15.

26. Brasil. Presidência da República. Secretaria Nacional de Políticas sobre Drogas. I Levantamento Nacional sobre o Uso de Álcool, Tabaco e Outras Drogas entre Universitários das 27 Capitais Brasileiras/Secretaria Nacional de Políticas sobre Drogas. Brasília: SENAD; 2010.

27. Abreu MNS, Souza CF, Caiaffa WT. Tabagismo entre adolescentes e adultos jovens de Belo Horizonte, Minas Gerais, Brasil: influência do entorno familiar e grupo social. Cad. Saúde Pública. 2011; 27(5): 935-943. DOI: 10.1590/S0102311X2011000500011.

28. Gásquez MAR, Botero SAP, Yépes LFV. Características del consumo de tabaco en estudiantes de enfermeira de la Universidad de Antioquia (Colombia). Invest educ enferm. 2010;28(3):370-383.

29. Newbury-Birch D, White M, Kamali J. Factors influencing alcohol and illicit drug use amongst medical students. Drug Alcohol Depend. 2000;59:125-130. DOI: https://doi.org/10.1016/S0376-8716(99)00108-8

30. Webb E, Ashton CH, Kelly P, Kamali F. An update on British medical students lifestyles. Med Educ. 2002;32:325-231. DOI: 10.1046/j.1365-2923.1998.00204.x

31. Mammas IN, Bertsias GK, Linardakis M, Tzanakis NE, Labadarios DN, Kafatos AG. Cigarette smoking, alcohol consumption, and serum lipid profile among medical students in Greece. Eur J Public Health. 2003;13:278-282.

32. Quadros TM, Petroski EL, Santos-Silva DA, Pinheiro-Gordia A. The prevalence of physical inactivity amongst Brazilian university students: its association with sociodemographic variables. Rev Salud Publica. 2009;11(5): 724-733.

33. Gasparotto GS, Gasparotto LPR, Salles MR, Campos W. Fatores de risco cardiovascular em universitários: comparação entre sexos, períodos de graduação e áreas de estudo. Medicina (Ribeirão Preto) 2013;46(2):154-163. DOI:10.11606/issn.21767262.v46i2p154-163

34. Petrib MMV, Cabral PC, Arruda IKG. Estado nutricional, consumo alimentar e risco cardiovascular: um estudo em universitários. Rev Nutr 2009;22(6):837-46. DOI: 10.1590/S141552732009000600005

35. Peltzer K, Pengpid S. Underestimation of weight and its associated factors in overweight and obese university students from 21 low, middle and emerging economy countries. Obesity research $\begin{array}{llll} & \text { clinical practice. 2015; } 9 & \text { (3):234-242. }\end{array}$ DOI:10.1016/j.orcp.2014.08.004

36. Pengpid S, Peltzer K. Prevalence of overweight/obesity and central obesity and its associated factors among a sample of univer- sity students in India. Obes Res Clin Pract. 2014; 8(6): e558e570. DOI: 10.1016/j.orcp.2013.12.003

37. Costa LCF, Vasconcelos FAG. Prevalence and factors associated with nutritional status among female university students in Florianópolis, SC. Rev bras cineantropom desempenho hum. 2013; 15(3): 326-337. DOI: 10.5007/1980-0037.2013v15n3p326

38. Almeida A, Beraldo CL, Magalhães EF, Lima JPR, Guimarães ML, Risso W. Tabagismo e sua relação com dados sociais, uso de álcool, café e prática de esporte, em estudantes da Universidade do Vale do Sapucaí (UNIVÁS), Pouso Alegre, MG-Brasil. Rev Med Minas Gerais. 2011;21(2):168-73.

39. Botelho C, Silva AMP, Melo CD. Tabagismo em universitários de ciências da saúde: prevalência e conhecimento. J bras pneumol. 2011;37(3):360-366. DOI: 10.1590/S180637132011000300013

40. Mann JI. Diet and risk of coronary heart disease and type 2 diabetes. Lancet. 2002;360:783-789.

41. Mendes-Netto RS, Silva CS, Costa D, Raposo OFF. Nível de atividade física e qualidade de vida de estudantes universitários da área de saúde. RBCS. 2012;10(34):47-55.

42. Paixão LA, Dias RMR, Do Prado WL. Estilo de vida e estado nutricional de universitários ingressantes em cursos da área de saúde do Recife/PE. Rev Bras Ativ Fís Saúde 2010;15(3):145-150.

43. Quadros TM, Petroski EL, Santos-Silva DA, Pinheiro-Gordia A. The prevalence of physical inactivity amongst Brazilian University Students: its association with sociodemographic variables. Rev Salud Pública 2009;11(5):724-733.

44. Silva DAS. Nível de atividade física e fatores associados em acadêmicos de educação física de uma universidade pública do nordeste do Brasil. Rev Bras Ativ Fís Saúde 2011;16(3):193-198.

45. El-Gilany A-H, Badawi K, El-Khawaga G, Awadalla N. Physical activity profile of students in Mansoura University, Egypt. East Mediterr Health J. 2011;17(8):694-702.

46. Mielke GI, Ramis TR, Habeyche EC, Oliz MM, Tessmer MGS, Azevedo MR, Hallal PC. Atividade física e fatores associados em universitários do primeiro ano da Universidade Federal de Pelotas. Revista Brasileira de Atividade Física \& Saúde. 2010; 15(1): 57-64.

47. Sabbah I, Sabbah H, Khamis R, Sabbah S, Droubi N. Health related quality of life of university students in Lebanon: Lifestyles behaviors and socio-demographic predictors. Health. 2013; 5(7A4): 1-12.

48. Duca GF, Rombaldi AJ, Knuth AG, Azevedo MR, Nahas MV. Associação entre nível econômico e inatividade física em diferentes domínios. Rev Bras Ativ Fis Saúde. 2009;14(2):123-131.

49. Chaves ES, de Araújo TL, Chaves DB, Costa AG, Oliveira AR, Alves FE. Children and adolescents with familiar history of high blood pressure: risk factors for cardiovascular diseases. Acta Paul Enferm. 2009;22(6):793-799.

50. Khan ZN, Assir MZ, Shafiq M, Chaudhary AE, Jabeen A. High prevalence of preobesity and obesity among medical students of Lahore and its relation with dietary habits and physical activity. Indian J Endocrinol Metab. 2016; 20: 206-210. DOI: 10.4103/2230-8210.176357

51. Florindo AA, Brownson RC, Mielke GI, Gomes GA, Parra DC, Siqueira FV, et al. Association of knowledge, preventive counseling and personal health behaviors on physical activity and consumption of fruits or vegetables in community health workers. BMC Public Health. 2015;15:344. DOI: 10.1186/s12889-015$1643-3$

52. Pinho CPS, Diniz AS, Arruda IKG, Lira PIC, Cabral PC, Siqueira LAS, et al. Consumo de alimentos protetores e preditores do risco 
cardiovascular em adultos do estado de Pernambuco. Rev Nutr. 2012;25(3):341-351. DOI: 10.1590/S1415-52732012000300004

53. Kolbe-Alexander TL, Conradie J, Lambert EV. Clustering of risk factors fornon-communicable disease and healthcare expenditure in employees with privatehealth insurance presenting for health risk appraisal: a cross-sectional study. BMC Public Health. 2013;13:1213. DOI:10.1186/1471-2458-13-1213

54. Veras VS, Monteiro LZ, Landim CAP, Xavier ATF, Pinheiro MHNP, Montenegro RM. Levantamento dos fatores de risco para doenças crônicas em universitários. RBPS. 2007;20:168172. DOI: $10.5020 / 1021$

\section{Corresponding author}

Luciana Zaranza Monteiro

Escola de Saúde

Centro Universitário do Distrito Federal

SEP/SUL EQ 704/904 Conj. A. Asa Sul. CEP: 70390-045.

Brasília, DF, Brasil.

E-mail: lucianazaranza@hotmail.com

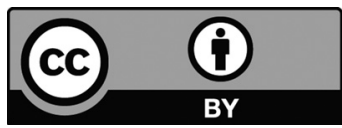

Manuscript received on July 25, 2019

Manuscript accepted on September 28, 2019

Motriz. The Journal of Physical Education. UNESP. Rio Claro, SP, Brazil eISSN: 1980-6574 - under a license Creative Commons - Version 4.0 